\title{
The Heat Storage Capacities of Mortars Containing Clinoptilolite Blended Cements
}

\author{
*1Y Yasemin Akgün and ${ }^{2}$ Talha Y1lmaz \\ ${ }^{1}$ Ordu University, Renewable Energy, Ordu, Turkey \\ *2Directorate of Environment and Urbanization, Ordu, Turkey
}

\begin{abstract}
Recently, the studies on the heat storage capabilities of building materials for energy efficient building design are becoming more widespread. In this study, the heat storage capacities of mortars produced with blended cement containing clinoptilolite that is the most valuanle of the natural zeolite minerals were investigated. The clinoptilolite which is used as replacement material and has the highest purity rate (96\% purity) in the world was obtained from Manisa-Gördes region. Firstly, the mortar samples containing clinoptilolite blended cements at $0,10,30$ and $50 \%$ replacement ratios were produced. And then, the physical, chemical, mechanical, petrographic properties, thermal conductivity and heat storage capacities of clinoptilolite rock were determined. The compressive strengths and thermal performance tests were performed on the mortar samples containing clinoptilolite blended cements. The test results were compared amongst themselves and with each other. According to the test results, it was concluded that heat storage capabilities of the mortars containing clinoptilolite blended cements could be improved.
\end{abstract}

Key words: Clinoptilolite, blended cement, heat storage, mortar, zeolite

\section{Introduction}

The renewable energy sources are economic and environmental technologies. They have been becoming more widespread in the construction sector that uses energy intensively. The rational using of solar energy which is one of the renewable energy sources is transformed into applications in energy efficient building designs. One of these applications is the storage of solar energy on building materials. Solar energy is a source of energy that has continuity in nature, can be effective only during the day and can be variation seasonal effect. Therefore, it has become an essential requirement developing a storage method. At the first applications of solar energy using in history, it is seen that the houses in the hot climatic zones are built with very thick walls that has large thermal masses, The heat collected during the day by walls releases at night and emitting coolness throughout the day. In order to use it at the appropriate time and store of solar energy in buildings, the researches are conducted on the thermal capabilities of building materials. Rocks containing zeolite minerals have positive properties such as high heat storage capacity and pozzolanic activity, low energy grindability, natural and local formation and reserve status. In addition, it is understood from the literature that the strength and durability of mortar/concrete samples containing certain amounts of zeolite improve. Some of these studies are given below. Basyigit [1] used blended cement containing clinoptilolite as replacement material with $0,5,10$ and $15 \%$ ratios in concrete. It was measured thermo-mechanical properties of concrete in the study. And, it was found that

*Corresponding author: Address: Institute of Science, Renewable Energy Ordu University, 52200, Ordu TURKEY. E-mail address: ysmakgun@gmail.com, Phone: +904522334865 
decreased by zeolite additive of thermal conductivity in concrete. Öcal [2] studied the effect of high temperature on some properties of natural zeolite blended concrete. In this context, 7 different concrete mixtures were prepared in $0,5,10,15,20,30$ and $40 \%$ replacement ratios by using natural zeolite. It has been concluded that the natural zeolite additive reduces the thermal conductivity coefficient of concrete. Özkahraman et al. [3] investigated thermal insulation effect on using as building material of tuffs containing analcime that is zeolite mineral at $15 \%$ ratio. They concluded that the zeolite tuff with $40 \%$ pore rate would obtained save up to $60 \%$ in term of air conditioning compared to the concrete on the outer walls of buildings. Bilgin [4] showed that natural zeolite mineral could be used in solar energy storage systems depending on adsorption and ion exchange properties. It mentioned that clinoptilolite and chabasite could be used as a heat exchanger and for heating small buildings. Dincer and Rosen [5] stated that zeolites are highly efficient materials in various thermal storage and solar-related air-conditioning activities thanks to their ability such as highly heat-absorbing and maintain structural stability while being hydrating/dehydrating. Karakurt et al. [6] used natural zeolite (clinoptilolite) as aggregate and binding factor in aerated concrete. According to the results, the thermal conductivity of the natural zeolite blended samples was lower than the control samples. Thus, it was concluded that the low-density material and a higher building insulation performance would be achieved by using aerated concretes containing natural zeolite in wall blocks. Sallı Bideci et al. [7] examined on the properties of cement mortar by using $0,5,10,15$ and 20 ratios of zeolite. In the study, the most suitable values in terms of blended cement properties were obtained from $10 \%$ zeolite blended cement mortars. Thus, it has been concluded that natural zeolite blended cement will contribute positively to energy saving and environmental pollution. Ahmadi and Shekarchi [8] compared the usability of zeolite obtained from Iran in concrete as pozzolan with silica fume. According to the results of the study, zeolite did not exhibit pozzolanic property as much as silica fume, but it contributed to mechanical strength more than silica fume.

The aim of this study is to determine how will effect of the heat storage capacities and the physicalmechanical properties of mortars containing natural and local zeolite (clinoptilolite) blended cements.

\section{Materials and Method}

The natural zeolite mineral, clinoptilolite, was replaced by Portland cement. The clinoptilolite (C) which is natural zeolite type was obtained from Manisa/Gördes regions of Turkey. The cement used in tests was CEM I 42.5 R type of Portland cement (PC) produced in accordance with EN 197-1 [9]. The PC was obtained from Unye Cement Company. In pozzolanic activity tests and strength tests of mortars, CEN (the European Committee for Standardization) standard sand in accordance with EN 196-1 [10] was used. In lime-pozzolan mixtures, slaked lime $\left(\mathrm{Ca}(\mathrm{OH})_{2}\right)$ was used as specified in TS 25 [11]. It was used melamine-based modified polymer superplasticizer (at $1,1.5$ and $2 \%$ ratios) complying with EN 934-2 [12] by adding to mixture water to recover of adverse effect on mortar consistency of natural zeolite. In production of all samples, the water that does not contain organic substances, harmful minerals or salts was used. The natural zeolite (clinoptilolite) sample was obtained by finely grinding in a ball mill so as to provide approximately $70 \%$ passing value through $45 \mu \mathrm{m}$ sieve. The amounts of zeolite used in mixtures were 0 (none), 
10 (low), 30 (medium) and 50 (high)\% of cement weight. The samples were produced with the labels PC, C10, C30, C50 for blended cement mixtures and MPC, MC10, MC30 MC50 for mortars. Density-specific surface (Blaine) of natural zeolite and cements were determined according to EN 197-1 and EN 196-6 [13], respectively. The tests for determination of pozzolanic activity of natural zeolite were made by mechanical test method which is determined with average compressive strengths of lime-pozzolan mixtures in accordance with TS 25. Chemical composition of zeolite was determined by X-ray fluorescence (XRF) analysis. This analysis was carried out by using desktop XRF (EDXRF) device as percentage (\%) with loss of ignition (LOI) amount on samples prepared as pellet in laboratory of "General Directorate of Mineral Research and Explorations" coded as "MTA". X-Ray Diffraction (XRD) analysis was performed to determine mineralogical composition of zeolite. This analysis was performed using a "Bruker D8 Advance" diffractometer (with $\mathrm{CuK} \alpha$-radiation and $\mathrm{Ni}$ filter) at $40 \mathrm{kV}$ and $40 \mathrm{~mA}$. The samples were scanned from $2 \theta, 2$ to $45^{\circ}$, at a scanning speed of $2 \% \mathrm{~min}$. The images for microstructure of zeolite were obtained using a Scanning Electron Microscope (SEM) that is brand of Hitachi, model of SU 1510 with EDX(Energy Dispersive X-ray Spectroscopy) sensor in "Ordu University, Central Research Laboratory" coded as "ODUMARAL". For SEM investigations, it was made gold plating to provide conductivity on zeolite samples which have fineness used in the study. For this, the surface of sample on the carbon band of the gold plating device (sputter) was plated with gold at a thickness of approximately 10-20nm with 20-30 mA. Mortar samples were prepared by applying the standard mixing, molding and curing procedures stated in EN 196-1. Samples were prepared in laboratory environment where temperatures are $20 \pm 2^{\circ} \mathrm{C}$ and relative humidity is $60 \pm 5 \%$. The sand-to-cement ratio of mortars was constantly 3 . The water-to-cement ratio of mortars was constantly 0.5 . The flow values of mortar mixtures are about $150 \pm 20 \mathrm{~mm}$. The thermal properties of mortars were performed by 20x $60 \times 150 \mathrm{~mm}$ molds at 28 days. The compressive strengths of mortars were determined by 50x50x50mm cube molds at 28 days. The strength developments of mortars were carried out in accordance with the EN 196-1. The results obtained from the test series were compared amongst themselves and with each other.

\subsection{Determination tests of thermal conductivity and heat storage}

The prepared mortar mixtures were poured into steel molds produced in accordance with the probes. They were kept in molds for 24 hours under laboratory conditions. Samples were cured in water for 28 days. The mortar samples were tested with thermal conductivity and heat storage value (heat capacity) meter, which is referred to with ISOMET 2104 code, in the Laboratory of Dicle University Mining Engineering Department. The thermal conductivity values $(\mathrm{k})$ and heat storage capacity values of mortars-rocks were determined as a result of the experiments carried out according to the principles of TS EN ISO 8990 [14] and ISO 6946[15] standards. The measuring device uses the hot wire method according to DIN 51046 [16], TS EN 993-15 [17]. The measurements were made at $22-25^{\circ} \mathrm{C}$ and five different points on each sample. The ISOMET 2104 is capable of measuring the heat conduction coefficient at a sensitivity of $5 \%$ in the range 0.04 $0.06 \mathrm{~W} / \mathrm{mK}$ and the volumetric specific heat at a sensitivity of $15 \%$ in the range $4.0 \times 104-4.0 \times 106$ $\mathrm{J} / \mathrm{m}^{3} \mathrm{~K}$. It has three different solid surface probes developed for the determination of thermal properties of hardened materials such as natural stones, rocks, mortar and concrete [18]. 


\section{Results and Discussion}

\subsection{Some properties of Portland cement, blended cements and natural zeolite}

Some properties of Portland cement (PC), blended cements and natural zeolite are given Tables 13 . The density of clinoptilolite is $32.37 \%$ lower than PC. The specific surface area of clinoptilolite is $27.07 \%$ higher than PC. This situation depends on mineral structure, porosity and fragilement properties of zeolite. The cumulative passing (\%) of $45 \mu \mathrm{m}$ sieve for Portland cement, clinoptilolite are $67.11 \%, 68.64 \%$, respectively. The densities of blended cements have decreased with increasing of zeolite ratios. The fineness of blended cements containing zeolite has increased with increasing of zeolite ratios (Fig. 1).

Table 1. Chemical composition, physical and mechanical properties of Portland cement (PC)

\begin{tabular}{|c|c|c|c|c|c|}
\hline \multirow{2}{*}{$\begin{array}{l}\text { Chemical composition } \\
\mathrm{SiO}_{2}\end{array}$} & \multirow{2}{*}{$\begin{array}{l}\text { (wt.\%) } \\
19.53\end{array}$} & \multicolumn{4}{|c|}{ Physical and mechanical properties of Portland cement } \\
\hline & & Density, $\left(\mathrm{g} / \mathrm{cm}^{3}\right)$ & 3.12 & Clinker & imple (\%) \\
\hline $\mathrm{Al}_{2} \mathrm{O}_{3}$ & 5.33 & Initial set, (h) & 2.50 & $\mathrm{C}_{3} \mathrm{~S}$ & 54.94 \\
\hline $\mathrm{Fe}_{2} \mathrm{O}_{3}$ & 3.56 & Final set, (h) & 4.15 & $\mathrm{C}_{2} \mathrm{~S}$ & 18.52 \\
\hline $\mathrm{CaO}$ & 62.26 & Volume expansion, mm & 2.00 & $\mathrm{C}_{3} \mathrm{~A}$ & 8.39 \\
\hline $\mathrm{MgO}$ & 0.99 & Specific surface (Blaine) $\left(\mathrm{cm}^{2} / \mathrm{g}\right)$ & 3210 & $\mathrm{C}_{4} \mathrm{AF}$ & 11.26 \\
\hline $\mathrm{SO}_{3}$ & 3.02 & The compressive strengths (MPa) & 2 days & 7 days & 28 days \\
\hline $\mathrm{Na}_{2} \mathrm{O}$ & 0.95 & & 32.30 & 44.60 & 53.00 \\
\hline $\mathrm{K}_{2} \mathrm{O}$ & 0.73 & Over sieve $(\%)$ & $45 \mu \mathrm{m}$ & $90 \mu \mathrm{m}$ & $200 \mu \mathrm{m}$ \\
\hline Loss of ignition & 3.06 & & 32.89 & 12.15 & 2.73 \\
\hline
\end{tabular}

Table 2. Physical properties and chemical compositions of natural zeolite

\begin{tabular}{lllc}
\hline Chemical composition & Clinoptilolite (wt.\%) & \multicolumn{2}{c}{ Physical properties } \\
\hline $\mathrm{SiO}_{2}$ & 64.70 & & Clinoptilolite \\
$\mathrm{Al}_{2} \mathrm{O}_{3}$ & 11.21 & Density, $\left(\mathrm{g} / \mathrm{cm}^{3}\right)$ & 2.11 \\
$\mathrm{Fe}_{2} \mathrm{O}_{3}$ & 1.38 & Blaine fineness $\left(\mathrm{cm}^{2} / \mathrm{g}\right)$ & 4079 \\
$\mathrm{CaO}$ & 2.08 & & \\
$\mathrm{MgO}$ & 0.79 & & Over sieve $(\%)$ \\
$\mathrm{Na}_{2} \mathrm{O}$ & 0.38 & $45 \mu \mathrm{m}$ & 31.36 \\
$\mathrm{~K}_{2} \mathrm{O}$ & 3.78 & $90 \mu \mathrm{m}$ & 11.51 \\
Loss of ignition & 11.80 & $200 \mu \mathrm{m}$ & 2.57 \\
\hline
\end{tabular}

Table 3. Physical properties of blended cements

\begin{tabular}{lllll}
\hline Physical properties & PC & C10 & C30 & C50 \\
\hline Specific surface $\left(\mathrm{cm}^{2} / \mathrm{g}\right)$ Blaine fineness & 3210 & 3408 & 3664 & 3898 \\
Density, $\left(\mathrm{g} / \mathrm{cm}^{3}\right)$ & 3.12 & 2.75 & 2.72 & 2.46 \\
\hline
\end{tabular}




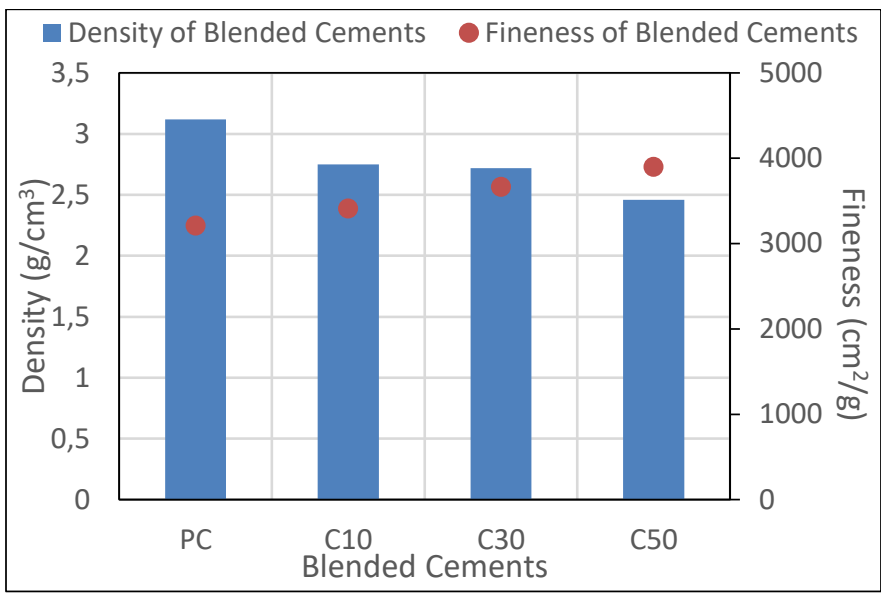

Figure 1. The density-fineness for blended cements

\subsection{Pozzolanic activity of natural zeolite}

The pozzolanic activity of natural zeolite depends on their chemical and mineralogical composition. Pozzolans are defined as materials with silica and alumina. The $\mathrm{SiO}_{2}$ and $\mathrm{Al}_{2} \mathrm{O}_{3}$ contents of natural zeolites react with calcium hydroxide released during the hydration of cement and convert it into CSH (Calcium-Silicate-Hydrate) gels and aluminates. Thus, due to the microstructure of hardened cement, strength of mortar/concrete is improved, And, the mortar/concrete becomes more impermeable [19]. In TS 25, the pozzolanic activity test is defined as a characteristic determined in terms of compressive strength of mortar obtained by mixing natural pozzolan, water, standard sand and calcium hydroxide $\left(\mathrm{Ca}(\mathrm{OH})_{2}\right)$. The amounts of materials required to prepare three test samples for tests on pozzolanic activity are given in Table 4. Pozzolanic activity value of natural zeolite (clinoptilolite) is given Table 5.

Table 4. The amounts of materials for tests on pozzolanic activity

\begin{tabular}{lll}
\hline & \multicolumn{1}{c}{ TS 25 } & \multicolumn{1}{c}{ The amounts for tests } \\
\cline { 3 - 3 } & & \multicolumn{1}{c}{ Clinoptilolite } \\
\hline Slaked lime $\left(\mathrm{CaOH}_{2}\right)$ & $150 \mathrm{~g}$ & $150 \mathrm{~g}$ \\
Pozzolan & $2 \times 150 \mathrm{x}\left(\right.$ density of poz. $/$ density of $\left.\mathrm{CaOH}_{2}\right)(\mathrm{g})$ & $2 \times 150 \times(2.11 / 2.15)=294.42 \mathrm{~g}$ \\
Standard sand & $1350 \mathrm{~g}$ & $1350 \mathrm{~g}$ \\
Water & $0.5 \times(150+$ pozzolan $)(\mathrm{g})$ & $0.5 \times(150+294.42)=222.21 \mathrm{~g}$ \\
\hline
\end{tabular}

Table 5. Pozzolanic activity values of natural zeolite

\begin{tabular}{ll}
\hline TS 25 limit values & Clinoptilolite \\
\hline Lime-pozzolan mix. 7 days compressive strength $>4 \mathrm{MPa}$ & $9.02 \mathrm{MPa}$ \\
$\mathrm{SiO}_{2}+\mathrm{Al}_{2} \mathrm{O}_{3}+\mathrm{Fe}_{2} \mathrm{O}_{3}$ wt. content $>70 \%$ & $77.30 \%$ \\
Specific surface area $>3000 \mathrm{~cm}^{2} / \mathrm{g}$ & $4079 \mathrm{~cm}^{2} / \mathrm{g}$ \\
\hline
\end{tabular}

According to Table 5, in TS 25, one of the conformities criterias for pozzolans is the 7 days compressive strength of samples prepared with lime-pozzolan mixture. The limit value of the compressive strength is at least $4 \mathrm{MPa}$. In tests performed for pozzolanic activity, the average 
compressive strength values for the lime-zeolite (pozzolan) mixture samples were determined as $9.02 \mathrm{MPa}$ for clinoptilolite. It has also been emphasized that the sum of $\mathrm{SiO}_{2}+\mathrm{Al}_{2} \mathrm{O}_{3}+\mathrm{Fe}_{2} \mathrm{O}_{3}$ in TS 25 should be at least $70 \%$ by mass. The value of this total was found to be $77.3 \%$ for clinoptilolite. At the same time, the specific surfaces of the pozzolans should be greater than $3000 \mathrm{~cm}^{2} / \mathrm{g}$. The specific surfaces of pozzolan which is used in this study were found to be $4079 \mathrm{~cm}^{2} / \mathrm{g}$ for clinoptilolite. It is seen that; the fineness of natural zeolite is higher than that of Portland cement. And, the content of silica and alumina are above of $70 \%$. Due to these values, the reaction which is between pozzolan and lime is increased. It is thought that, this situation is caused an increment at the value of pozzolanic activity. The results show that the zeolite used in the study have usable potential as a pozzolan.

\subsection{Mineralogical analysis of natural zeolite}

The results of mineralogical analysis of natural zeolite are given below. XRD diffraction patterns and SEM images of zeolite are presented Figs. 2-3. The clinoptilolite sample was obtained from Gördes Zeolite Company. The main component in the sample $(>50 \%)$ is "clinoptilolite" that is a zeolite group mineral and is a member of hoylandite-clinoptilolite isomorphic series. The ratio of clinoptilolite in the sample is 80-85\%. Clinoptilolite (Silicate-Zeolite Group Mineral) (80-85\%), Opal-CT (Opal-Kritobalite/Tridimite) (Silicate-Silice Group Mineral) (10-15\%), Quartz (SilicateSilice Group Mineral (\% <2)), Feldspar ( $\mathrm{Na}$ and K-Felspat) (Silicate-Feldspate Group Mineral) $(<2 \%)$, Illite-Mica (Silicate-Clay-Mica Group Mineral) $(\%<5)$. As other minerals; opal-CT is a certain rate, illite mica, quartz and feldspar are low and trace rates. According to the mineral ratios at the mineralogical composition results determined by the X-ray diffraction analysis (XRD) of clinoptilolite sample, the sample is characterized by zeolite industrial raw material. When the diffractogram and SEM image of zeolite are examined, as seen that zeolite contains clinoptilolite as dominant minerals. And, it has crystal structure.

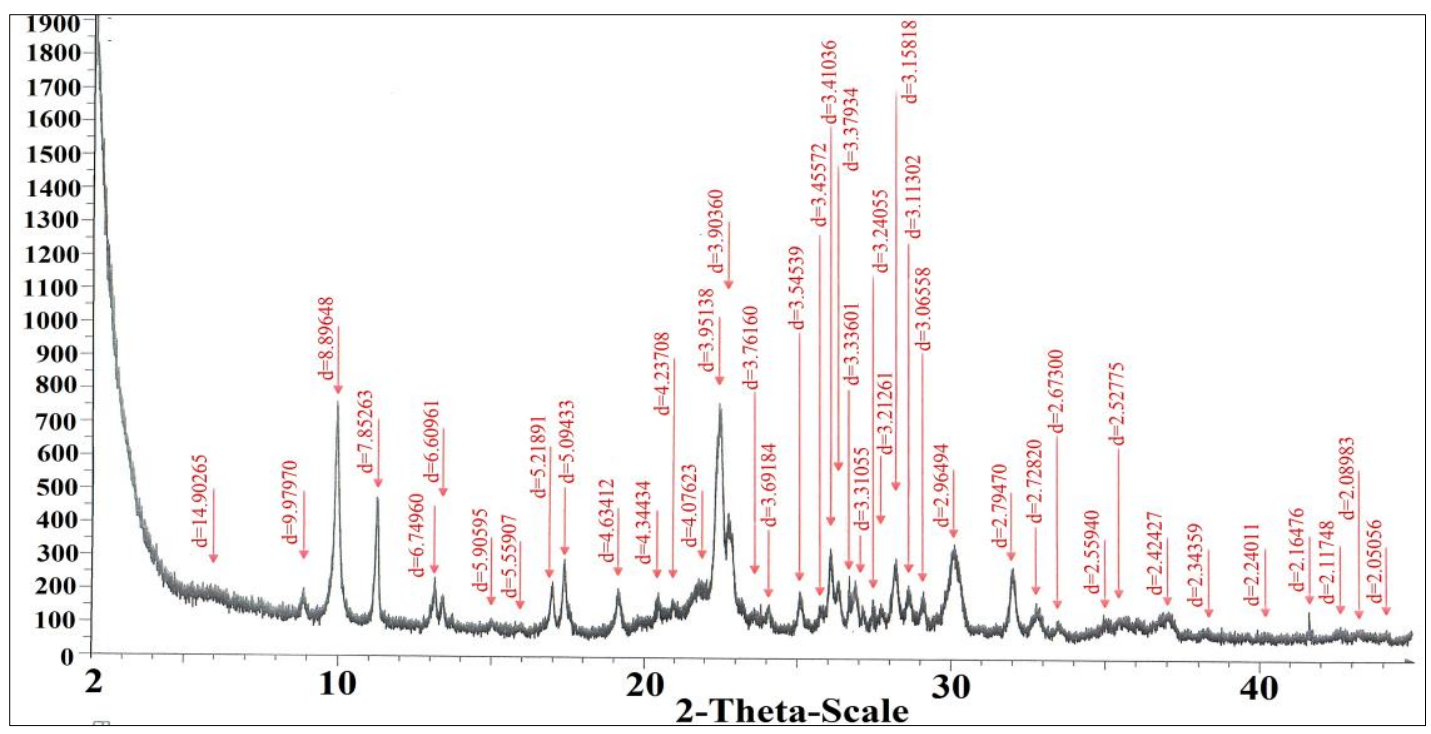

Figure 2. XRD patterns of clinoptilolite (Gördes Zeolite Company) 

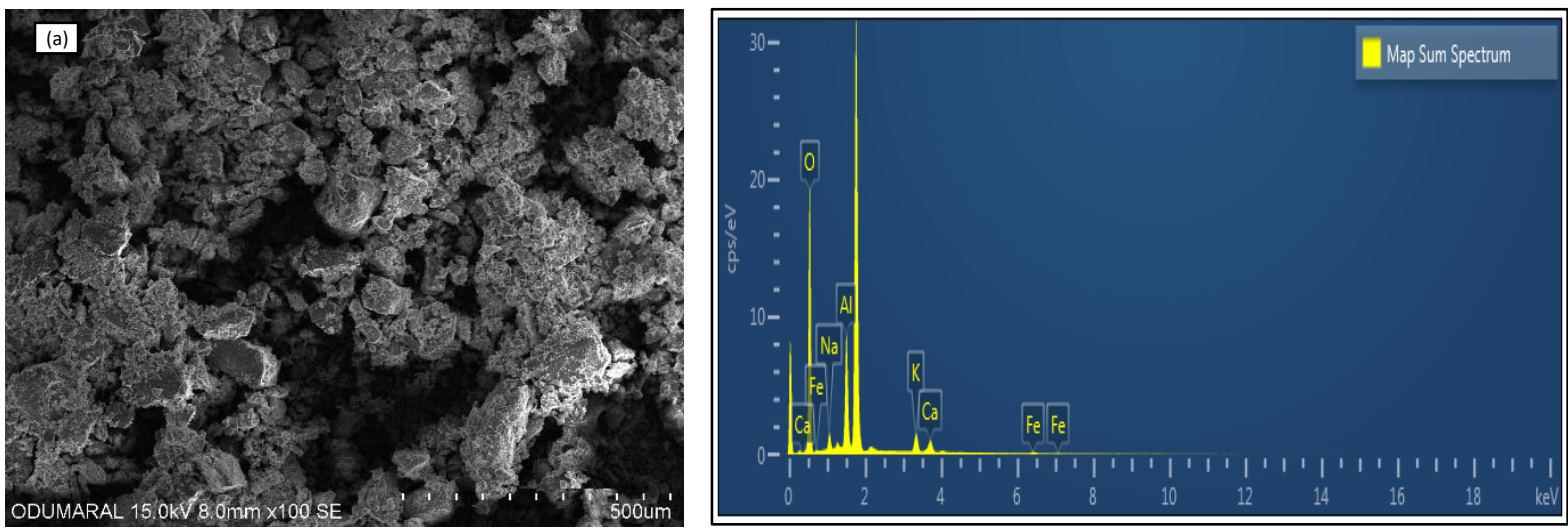

Figure 3. SEM image (a) and EDS (b) of clinoptilolite sample

\subsection{The compressive strengths of mortars}

The compressive strengths and densities of mortars are given in Table 6 . The variation graphs of their are given in Fig. 4. According to the Table 6, the densities of the mortars containing clinoptilolite blended cements decrease with the increasing of clinoptilolite ratios due to the low density of clinoptilolite. The compressive strengths of mortars meet the minimum strength value specified in TS EN 197-1 up to $10 \%$ replacement ratio.

Table 6. The compressive strengths and densities of mortars

\begin{tabular}{ccc}
\hline Mortars & Density $\left(\mathrm{g} / \mathrm{cm}^{3}\right)$ & Compressive strength $(\mathrm{MPa})$ \\
\hline MPC & 2.32 & 54.96 \\
MC10 & 2.16 & 50.79 \\
MC30 & 2.15 & 41.08 \\
MC50 & 2.01 & 24.97 \\
\hline
\end{tabular}

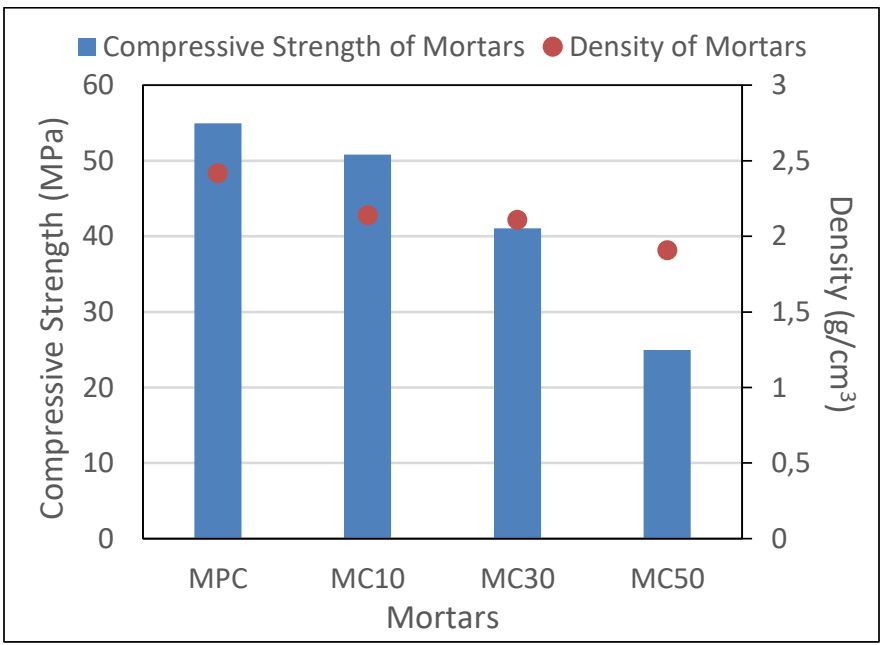

Figure 4. The compressive strengths and densities of mortars 


\subsection{Thermal conductivity and heat storage of clinoptilolite rock}

For solid materials used in heat storage, density $(\rho),\left(\mathrm{kg} / \mathrm{m}^{3}\right)$, specific heat $\left(\mathrm{c}_{\mathrm{p}}\right),(\mathrm{J} / \mathrm{kgK})$, thermal conductivity $(\mathrm{k}),(\mathrm{W} / \mathrm{mK})$ and thermal diffusivity $(\alpha),\left(\mathrm{m}^{2} / \mathrm{s}\right)$ are important factors that determine heat storage capability. In the calculation of thermal conductivity coefficient $(\mathrm{k})$, $\mathrm{q}$; heat flow through section $\mathrm{A}, \Delta \mathrm{T}$; temperature difference in thickness $\Delta \mathrm{L}$. It is determined by $\mathrm{k}=q \cdot(\Delta \mathrm{L} / \Delta \mathrm{T})$ equation. The smaller the thermal conductivity coefficient $(\mathrm{k})$ of a material, the better the insulation. The thermal diffusivity coefficient which is a thermophysical property shows how fast the heat is dissipated in the material. In the calculation of the thermal diffusivity coefficient $(\alpha), \mathrm{k}$; thermal conductivity coefficient, $\rho$; density, $\mathrm{c}_{\mathrm{p}}$; specific heat. It is determined by $\alpha=\mathrm{k} /$ ( $\rho . c p$ ) equation. Low thermal diffusivity means that most of the heat is absorbed by the material and very little amount is transmitted [20]. The $\mathrm{C}=\rho$.cp equation used in heat transfer is called the heat capacity of a material. Heat capacity indicates the heat storage ability of a material. The density, thermal conductivity $(\mathrm{k})$, specific heat $\left(\mathrm{c}_{\mathrm{p}}\right)$, heat capacity $(\mathrm{C})$ and thermal diffusivity coefficient $(\alpha)$ obtained from the thermal performance tests performed on the clinoptilolite rock are given in Table 7.

Table 7. Thermal properties of clinoptilolite rock

\begin{tabular}{llllll}
\hline Natural zeolite & $\begin{array}{l}\text { Density } \\
(\rho)\left(\mathrm{kg} / \mathrm{m}^{3}\right)\end{array}$ & $\begin{array}{l}\text { Thermal } \\
\text { conductivity } \\
(\mathrm{k})(\mathrm{W} / \mathrm{mK})\end{array}$ & $\begin{array}{l}\text { The specific heat } \\
\left(\mathrm{c}_{\mathrm{p}}\right)(\mathrm{J} / \mathrm{kg} \cdot \mathrm{K})\end{array}$ & $\begin{array}{l}\text { The heat capacity } \\
\mathrm{C}=\left(\rho \cdot \mathrm{c}_{\mathrm{p}}\right) \times 10^{-6} \\
\left(\mathrm{~J} / \mathrm{m}^{3} \cdot \mathrm{K}\right)\end{array}$ & $\begin{array}{l}\text { Thermal diffusivity } \\
\text { coefficient } \\
\left(\alpha=\mathrm{k} /\left(\rho \cdot \mathrm{c}_{\mathrm{p}}\right) \mathrm{x}\left(10^{-6}\right)\left(\mathrm{m}^{2} / \mathrm{s}\right)\right.\end{array}$ \\
\hline Clinoptilolite & 2110 & 0.61 & 777.25 & 1.64 & 0.37 \\
\hline
\end{tabular}

\subsection{Thermal conductivity and heat storage values of mortars}

Thermal conductivity and heat storage values of mortars are given in Table 8 . The heat capacitiesspecific heats and thermal conductivity-density of mortars are given in Fig. 5-6.

Table 8. Thermal properties of mortars

\begin{tabular}{cccccc}
\hline Mortars & $\begin{array}{l}\text { Density } \\
(\rho)\left(\mathrm{kg} / \mathrm{m}^{3}\right)\end{array}$ & $\begin{array}{l}\text { Thermal } \\
\text { conductivity } \\
(\mathrm{k})(\mathrm{W} / \mathrm{mK})\end{array}$ & $\begin{array}{l}\text { The specific heat } \\
\left(\mathrm{c}_{\mathrm{p}}\right)(\mathrm{J} / \mathrm{kg} . \mathrm{K})\end{array}$ & $\begin{array}{l}\text { The heat capacity } \\
\mathrm{C}=\left(\rho . \mathrm{c}_{\mathrm{p}}\right) \times 10^{-6} \\
\left(\mathrm{~J} / \mathrm{m}^{3} . \mathrm{K}\right)\end{array}$ & $\begin{array}{l}\text { Thermal diffusivity } \\
\text { coefficient } \\
\left(\alpha=\mathrm{k} /\left(\rho \cdot \mathrm{c}_{\mathrm{p}}\right) \times\left(10^{-6}\right)\left(\mathrm{m}^{2} / \mathrm{s}\right)\right.\end{array}$ \\
\hline MPC & 2300 & 2.75 & 730.43 & 1.68 & 1.64000 \\
MC10 & 2230 & 2.72 & 865.47 & 1.93 & 1.40933 \\
MC30 & 2170 & 2.48 & 811.06 & 1.76 & 1,40909 \\
MC50 & 2110 & 2.31 & 810.17 & 1.71 & 1.35087 \\
\hline
\end{tabular}

According to the results, the thermal conductivity $(\mathrm{k})$ values of mortars containing zeolite blended cement decrease as the zeolite replacement ratio increases. On the other hand, in all replacement ratios, the heat capacity of zeolite blended mortars are higher than that of Portland cement blended mortars. Accordingly, it is possible to say that the thermal insulation and heat storage ability of mortars containing zeolite blended cement is improved. The thermal diffusivity coefficients of mortars containing zeolite blended cement are lower than that of mortars containing Portland cement. This means that most of the heat is absorbed by the material and very little is transmitted. 


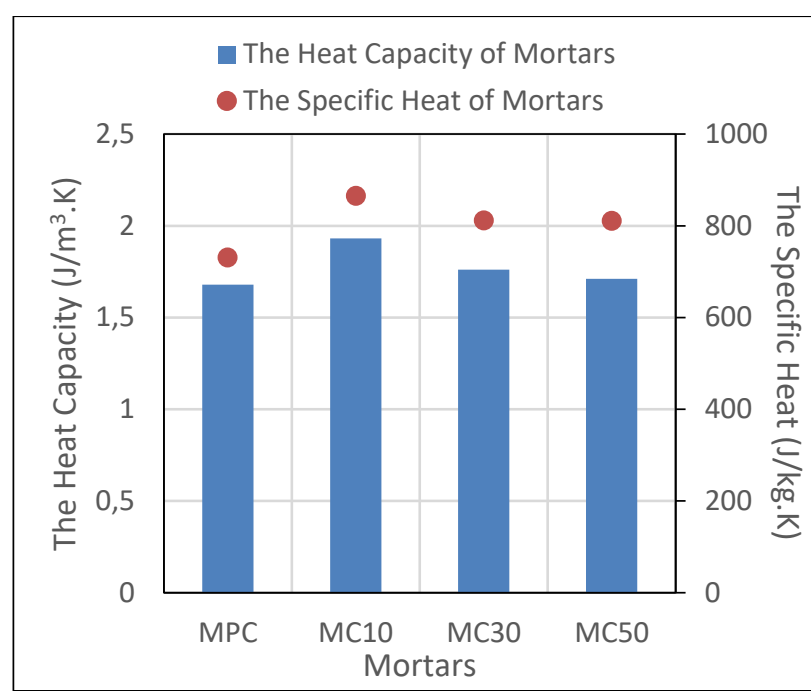

Figure 5. The heat capacities-specific heats of mortars

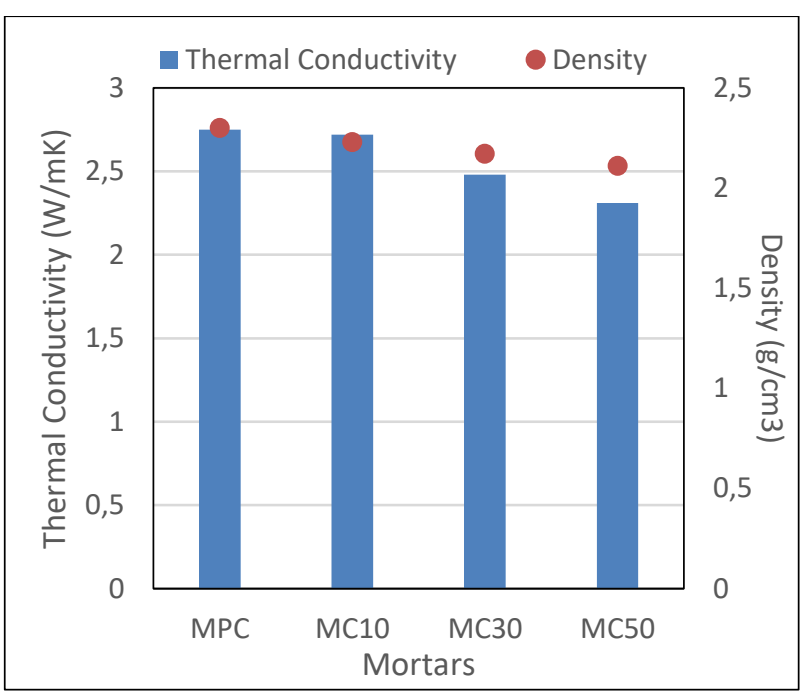

Figure 6. Thermal conductivities-densities of mortars

\section{Conclusions}

The pozzolanic activity of natural zeolite clinoptilolite determined according to TS 25 is $9.02 \mathrm{MPa}$. In mortar samples, compressive strengths of mortars decrease when natural zeolite replacement ratios increase. The compressive strength of mortar containing clinoptilolite blended cement at $10 \%$ replacement ratio is achieved an acceptable value. The heat capacities of mortars containing clinoptilolite blended cement are higher than that of mortars containing Portland cement. The thermal conductivity $(\mathrm{k})$ values of mortars containing zeolite blended cement decrease as the zeolite replacement ratios increase. Accordingly, it is possible to say that the thermal insulation of mortars containing zeolite blended cement is improved. The thermal diffusivity coefficients of mortars containing zeolite blended cement are lower than that of mortars containing Portland cement. The low thermal diffusivity means most of the heat is absorbed by the material and very little is transmitted. The heat storage ability (highest specific heat value) of mortars containing natural zeolite clinoptilolite was observed in MC10 test series. In summary, the blended cement production containing natural zeolite clinoptilolite that has pozzolanic properties provides some advantages in terms of heat storage. And, when heat capacities and compressive strengths of mortars containing zeolite both evaluated together, it is thought that to be $10 \%$ of optimum replacement ratio.

\section{Acknowledgements}

This study was funded by the Scientific Research Project Unit of Ordu University under Project No: BY-1736. The author would like to thanks to Laboratories of Dicle University, Laboratories of General Directorate of Mineral Research and Explorations, Gördes Zeolite and Votorantim Cement companies. 


\section{References}

[1] Basyigit C. The effect of zeolit rate on the thermo-mechanical properties of concrete. International Journal of the Physical Sciences 2010; 5:7,968-971.

[2] Öcal R. Yüksek sıcaklığın doğal zeolit katkılı betonlar üzerindeki etkisi. Yüksek Lisans Tezi, Niğde Üniversitesi, Fen Bilimleri Enstitüsü, İnşaat Mühendisliği Anabilim Dalı, Niğde 2014.

[3] Özkahraman HT, Işık EC. Isparta kaynaklanmış tüflerinin kaplama taşı olarak kullanılmasının önemi ve uygun yapıştırma harcı üretimi. IV. Mermer Sempozyumu, 18-19 Aralı, Afyon 2003.

[4] Bilgin Ö. Natural zeolite minerals as storage of energy. International Journal of Engineering Research \& Technology, 2014;3:2, 741-744.

[5] Dincer I. Rosen M. Thermal energy storage: Systems and Applications. John Wiley \& Sons, New York, USA, 2002, 237pp.

[6] Karakurt C. Topçu I.B. Effect of blended cements produced with natural zeolite and industrial by-products on alkali-silica reaction and sulfate resistance of concrete. Construction and Building Material, 2011;25:1789-1795.

[7] Sallı Bideci Ö. Bideci A. Oymael S. Zeolit katkılı çimento özelliklerinin incelenmesi, Süleyman Demirel Üniversitesi Uluslararası Teknolojik Bilimler Dergisi, 2013;5:3, 70-76.

[8] Ahmadi B. Shekarchi M. Use of natural zeolite as a supplementary cementitious material. Cement \& Concrete Composites. 2010; 32:134-141.

[9] EN 197-1, 2012. Cement-Part 1: Composition, specification and conformity criteria for common cements.

[10] EN 196-1, 2016. Methods of testing cement - Part 1: Determination of strength.

[11] TS 25, 2011. Natural pozzolan (Trass) for use in cement and concrete-Definitions, requirements and conformity criteria. Turkish Standarts Institute Ankara Turkey.

[12] EN 934-2, 2013. Admixtures for concrete, mortar and grout - Part 2: Concrete admixtures Definitions, requirements, conformity, marking and labelling.

[13] EN 196-6, 2010. Methods of testing cement- Part 6: Determination of fineness.

[14] EN ISO 8990, 1989. Thermal insulation-Determination of steady-State thermal transmission properties-Calibrated and guarded hot box.

[15] EN ISO 6946, 2017. Building components and building elements - Thermal resistance and thermal transmittance - Calculation methods.

[16] DIN 51046, 1976. Testing of ceramic materials; determination of thermal conductivity up to $1600^{\circ} \mathrm{C}$ according to the hot wire method, thermal conductivity up to $2 \mathrm{~W} \times \mathrm{K}^{-1} \times \mathrm{m}^{-1}$. Deutsches Institut für Normung.

[17] EN 993-15, 2006. Methods of test for dense shaped refractory products - Determination of thermal conductivity by the hot-wire (parallel) method.

[18] Devecioğlu A.G. Biçer Y. Genleştirilmiş kil agregalı betonların 1sıl özelliklerinin incelenmesi. Dicle Üniversitesi Mühendislik Fakültesi Dergisi. 2012; 3:2, 75-81.

[19] Gervais C. Ouki S.K. Performance study of cementitious systems containing zeolite and silica fume: effects of four metal nitrates on the setting time, strength and leaching characteristics. Journal of Hazardous Materials 2002; 93:187-200.

[20] Çengel, Y., Isı ve kütle transferi. Güven Yayınevi, İzmir 2011. 